\title{
Crowds and political violence in early modern Ireland: Galway and the 1641 depositions
}

\author{
JOHN WALTER* \\ University of Essex
}

\begin{abstract}
A B S T R A C T. This article offers a critical analysis of the representation of early modern popular violence provided by the 1641 depositions. Exploring the problems of how reported 'speech' was produced and recorded in the 1641 depositions, the article challenges the tendency within the depositions to represent violence as a spontaneous and immediate act, explicable by a racialised reading of Irish 'barbarity' and Catholic treachery. Exploiting a large cache of depositions and examinations in the relatively resource-rich urban context of Galway, it offers a micro-historical narrative of two brutal episodes of popular violence there in 1642 to reveal the complex histories and politics that might lie behind acts of violence in the Irish rising. Examining the local impact of the state's policies of anglicisation and Protestantisation, the paper recovers the prolonged, but ultimately unsuccessful, negotiations that preceded popular violence. Contextualizing the episodes, the article locates that violence in the more complex (and divided) politics of the city and in the radical challenges it brought to traditional structures of rule in Galway. Referencing the developing body of work on the politics of early modern crowd actions in Ireland, the article argues that the popular violence was political, both a consequence of and contributor to political change there.
\end{abstract}

$\mathrm{T}$ o write about violence in the 1641 Irish rising is to enter a historiographical and political minefield. Almost from the outset of the rising, the violence became the focus of debate. Employing early modern variants of the familiar language of the mob, Old English Confederate activists and apologists sought to blame 'the rascal multitude' and to locate their involvement in the politics (such as it was) of class. During the rising and in the near-contemporary histories that followed it, 'the cultivated', as Toby Barnard notes, 'disowned the cruelties of their compatriots'. Paradoxically, the New English administration and Protestant 'histories' also subscribed to a concept of the politics of the 'many-headed monster'. But, attributing popular violence to Catholic cruelty and Irish bloodlust, they blamed a Catholic elite for leading or licensing the mob. This consensus has seen histories of the period continue to reproduce contemporary prejudice as fact. According to a 2008 book on seventeenth-century Ireland, the popular revolt 'was a spontaneous, uncontrolled and sometimes murderous outburst by the lower classes of native

* John Walter, Department of History, University of Essex, jwalter@essex.ac.uk.

1 Toby Barnard, "Parlour entertainment in an evening"? Histories of the 1640s' in Micheál Ó Siochrú (ed.), Kingdoms in crisis: Ireland in the 1640s (Dublin, 2001), pp 20-43, at p. 40. 
society'. ${ }^{2}$ When married with the familiar, but for Ireland more acute problem of locating sources to write histories of the early modern crowd, this helps to explain the limited work on patterns of popular protest before the eighteenth century and almost nothing on the possibilities of a popular politics either before or during the 1641 Rising. But recent work has begun to address this absence, opening up the possibility of recovering patterns of protest against which to re-assess the potentially rich evidence of popular violence to be found in the 1641 depositions. ${ }^{3}$ This article seeks to contribute to that welcome development, offering a micro-historical analysis of popular violence in Galway in early 1642.

The 1641 depositions offer rich possibilities. ${ }^{4}$ Their numbers alone — it has been estimated that there are some 8,000 depositions - offer a striking contrast to the pre-1641 record where the absence or near-absence of many classes of documentation means that evidence of earlier crowd actions and popular violence is thin and patchy. The depositions have been the focus of fine and, given the scale of the records, heroic work by both academic and local historians. ${ }^{5}$ Much of this work

${ }^{2}$ Pádraig Lenihan, Consolidating conquest: Ireland 1603-1727 (Harlow, 2008), p. 97.

${ }^{3}$ See, for example, A. J. Sheehan, 'The recusancy revolt of 1603: a re-interpretation' in Archiv. Hib., xxxviii (1983), pp 3-13; Clodagh Tait, "Disorder and commotion": urban riots and popular protest in Ireland, 1570-1640' in Maura Cronin and William Sheehan (eds), Riotous assemblies: rebels, riots and revolts in Ireland (Cork, 2011), pp 22-49; eadem, 'Riots, rescues and "grene bowes": Catholics and protest in Ireland, 1570-1640' in Robert Armstrong and Tadhg Ó hAnnracháin (eds), Insular Christianity: alternative models of the church in Britain and Ireland, c.1570-c.1700 (Manchester, 2013), pp 67-87; David Edwards, Pádraig Lenihan and Clodagh Tait (eds), Age of atrocity: violence and political conflict in early modern Ireland (Dublin, 2007); David Edwards, 'Out of the blue? Provincial unrest in Ireland before 1641' in Micheál Ó Siochrú and Jane Ohlmeyer (eds), Ireland 1641: contexts and reactions (Manchester, 2013), pp 95-114; Stephen Carroll, 'Government policy, strategies of negotiation and the politics of protest in early seventeenthcentury Ireland' (Ph.D. thesis, Trinity College, Dublin, 2013).

${ }^{4}$ The 1641 depositions are held at Trinity College Library, TCD MS 809-841. They are available online at http://1641.tcd.ie/index.php. The Irish Manuscripts Commission is currently publishing the depositions in book form.

${ }^{5}$ Michael Perceval-Maxwell, The outbreak of the Irish rebellion of 1641 (Montreal, 1994); Nicholas Canny, 'The 1641 depositions as a source for the writing of social history: County Cork as a case study' in Patrick O'Flanagan and Cornelius Buttimer (eds), Cork: history and society (Dublin, 1993), pp 249-308; idem, 'What really happened in Ireland in 1641 ' in Jane Ohlmeyer (ed.), Ireland: from independence to occupation 1641-1660 (Cambridge, 1995), pp 24-42; idem, 'Religion, politics and the Irish rising of 1641' in Judith Devlin and Ronan Fanning (eds), Religion and rebellion: Historical Studies XX (Dublin, 1997), pp 43-68; idem, Making Ireland British 1580-1650 (Oxford, 2001), pp 461-550; Joseph Cope, England and the 1641 Irish rebellion (Woodbridge, 2009); Eamon Darcy, Annaleigh Margey and Elaine Murphy (eds), The 1641 depositions and the Irish rebellion (London, 2012); Eamon Darcy, The Irish rebellion of 1641 and the Wars of the Three Kingdoms (Woodbridge, 2013); Ó Siochrú \& Ohlmeyer (eds), Ireland 1641; Ciska Neyts, 'The rider on the horse: warfare during the outbreak of the 1641 Rebellion in four Ulster counties' (M. Phil. thesis, Trinity College, Dublin, 2010); Raymond Gillespie, 'Mayo and the rising of 1641' in Cathar Na Mart, v, no. 1 (1985), pp 38-44; Hilary Simms, 'Violence in County Armagh' in Brian MacCuarta (ed.), Ulster 1641: aspects 
continues to be marked by a concern to reassess the historical record of theft and violence, and to rescue it from the political uses to which the depositions were put from the outset, with the early selections in the contemporaneous 'histories' published by the English parliament's authority. ${ }^{6}$

But despite the promise of the 1641 depositions, there remain problems of interpretation. The depositions were drafted from notes taken in response to interrogatories, which do not always survive but whose list of priorities, reflecting the shifting focus of successive commissions, constrained what might be deposed. ${ }^{7}$ Where there were apparently no interrogatories to structure the depositions, the unstated agenda and attitudes shared by New English commissioners and deponents towards 'Irish' rebels doubtless influenced what was said and how it was recorded. Because of this, recent, often interdisciplinary, work has worried about the consequences of the power-saturated context within which 'speech' was produced and, therefore, about the relationship between text and event. In the recording of words spoken there is the problematic question of the slippage in reported speech between what was asked, what was (allowed to be) said and what was recorded, and in whose words. ${ }^{8}$ These problems are, of course, most evident with the examinations embedded in the 1641 depositions, but taken in the early 1650 s to be used by the High Court of Justice and by the Cromwellian delinquency commission. ${ }^{9}$ Although Irish Catholics were more likely to be found testifying (sometimes for their lives) in the records of the 1652 commissions, the voices to be heard in the 1641 depositions were overwhelmingly Protestant and English. Speech, then, was mediated in the 1641 depositions by the structures of power (and their shifting

of the rising (Belfast, 1993); Bríd McGrath, 'County Meath from the depositions' in Riocht na Midhe, ix, no. 1 (1994/95), pp 24-41; Brendan Scott, 'The 1641 Rising in the plantation town of Belturbet' in Breifne, x, no. 40 (2004), pp 155-75; Charlene McCoy and Micheál Ó Siochrú, 'County Fermanagh and the 1641 depositions' in Archiv. Hib., lxi (2008), pp 62136; Brendan Scott, 'Reporting the 1641 Rising in Cavan and Leitrim' in Brendan Scott (ed), Culture and society in early modern Breifne/Cavan (Dublin, 2009), pp 200-14; Jason McHugh, "For our owne defence": Catholic insurrection in Wexford, 1641-2' in Brian MacCuarta (ed.), Reshaping Ireland 1550-1700: colonization and its consequences (Dublin, 2011); Andrew Robinson, 'The outbreak of the 1641 Rising in County Monaghan' in P. J. Duffy and Éamon Ó Ciardha (eds), Monaghan: history and society. Interdisciplinary essays on the history of an Irish county (Dublin, 2017), pp 225-50.

6 Toby Barnard, 'The uses of 23 October 1641 and Irish Protestant celebrations' in Eng. Hist. Rev., cvi (1991), pp 889-920; idem, "Parlour entertainment in an evening"'.

${ }^{7}$ For the process by which the depositions were created, see Aidan Clarke (ed.), 1641 depositions, vol. XII: Connacht, Westmeath and Longford (Dublin, 2020), pp xlii-1.

${ }^{8}$ For a positive assessment of the process of deposing in 1641, see Marie-Louse Coolahan, "'And this deponent further sayeth": orality, print and the 1641 depositions' in Marc Caball and Andrew Carpenter (eds), Oral and print culture in Ireland, 1600-1900 (Dublin, 2010), pp 69-84. For the counter argument that the language of the depositions was constrained by context and purpose, see Barbara Fennell, 'Routine appropriation: women's voices and women's experiences in the 1641 depositions' in Journal of Irish and Scottish Studies, vi, no. 2 (2013), pp 52-70. For linguistic analysis of the depositions, see Nicci MacLeod and Barbara Fennell, 'Lexico-grammatical portraits of vulnerable women in war: the 1641 depositions' in Journal of Historical Pragmatics, xiii (2012), pp 259-90.

${ }^{9}$ For which, see John Cunningham, 'Anatomising Irish rebellion: the Cromwellian delinquency commission, the books of discrimination and the 1641 depositions' in I.H.S., xl, no. 157 (May 2016), pp 22-42; Clarke (ed.), 1641 depositions, XII, xl-xli, 1-lii. 
agendas), and by issues of gender, ethnicity, social status (on which too little has yet been done) and confessional identities.

With notable exceptions, depositions dealing with violent acts can be surprisingly terse, especially when deponents were testifying from hearsay. Many, perhaps most, depositions describe violence as an immediate act - a stabbing or a killing - rather than narrating the episode as an event or detailing the interactions that led to the violence. Even when the depositions apparently offer more detailed descriptions of the violence, there is a slippage between textualised reporting and the complexity of the event itself. Few, if any, hint at the pre-existing relationship(s) between victim(s) and attacker(s) predating the outbreak of the rising that might help to explain the selection and treatment of victims. ${ }^{10}$ Recovering the backstory to violence and contextualising acts of violence is rendered more difficult for early modern Ireland, given the well-known problem of the unevenness and thinness of sources, a product of both the 1922 destruction of much of the national archive and the relative underdevelopment of record-creating and record-keeping state institutions, especially in the provinces.

All this presents a problem perhaps more pressing than has yet been recognised in evaluating the evidence the 1641 depositions provide of violence. Rendering violence as an act suggests an immediacy of violence that has subtle (and not so subtle) consequences for its representation within the depositions. This is compounded by the other powerful trope of anti-popery that represented Catholics as inherently treacherous and cruel. Framed or read within the racialised trope of the 'wild and barbarous Irish', this could serve to render redundant any further need to explain the violence. ${ }^{11}$

This article explores these problems by seeking to contextualise two episodes of violence at Galway in March and April 1642. It exploits the multiple accounts these events created within the 1641 depositions in a relatively resource-rich urban context to reveal the complex histories and politics that might lie behind the immediate act of violence. The episodes of violence in Galway were the focus of subsequent investigation, with testimonies taken in the 1640s and again in the 1650s. These offer multiple perspectives on the episodes from victims and eyewitnesses but, it should be noted, from only a few of the accused and almost none of the bulk of the town's population. ${ }^{12}$ From January 1642 , the remit of the Commission for the Despoiled Subjects included investigation of killings. ${ }^{13}$ This, together with the evident use of interrogatories and the focus in the 1652 commissions on

${ }^{10}$ For a telling example, see Raymond Gillespie, 'The murder of Arthur Champion and the 1641 Rising in Fermanagh' in Clogher Rec., xiv, no. 3 (1993), pp 52-66.

${ }^{11}$ Aidan Clarke, 'The 1641 Irish rebellion and anti-popery in Ireland' in MacCuarta (ed.), Ulster 1641.

12 T.C.D., MS 830 has thirty-eight relevant depositions (with one group deposition and a couple of deponents deposing or having their testimony recorded twice). Eleven were taken between 1642 and 1645, twenty-seven between 1652 and 1654. Ethnic identities were not specified, but just under half the deponents were New English, less than a handful native Irish and most of the rest Old English. All were resident in Galway at the time of the violence; many were eyewitnesses or victims of the events, but less than a handful were direct participants in the violence.

${ }^{3}$ For analysis of the commissions, see Aidan Clarke, 'The 1641 depositions' in Peter Fox (ed.), Treasures of the library: Trinity College, Dublin (Dublin, 1984), pp 111-22; idem, 'The commission for the despoiled subjects, 1641-7' in MacCuarta (ed), Reshaping Ireland 1550-1700, pp 241-60. 
identifying and prosecuting those guilty of murder and massacre, tightly structured the focus of the evidence recorded. ${ }^{94}$ In particular, as Aidan Clarke has noted, many of the examinations taken about Galway in the 1650s were structured by the attempt to implicate in the murders Patrick Darcy, the Galway lawyer and a leading figure in the Confederate government. ${ }^{15}$

The evidence from the depositions can be related to the voluminous letter books of the neighbouring earl of Clanricarde (who, as governor of the town and county of Galway, was to play an active role in seeking first to avoid violence and then to curtail its consequences), ${ }^{16}$ and to the more taciturn records of the corporation. ${ }^{17}$ Contextualising the violence reveals the prolonged but ultimately unsuccessful negotiation that preceded its occurrence. It locates that violence in the more complex (and divided) politics of a city and in the radical challenge it brought to traditional structures of government in Galway. In both episodes the violence was in large part a response to policies in state and church.

In the early morning of Friday, 19 March 1642, a ship was attacked while riding at anchor in Galway harbour. Recently returned from La Rochelle in France, the Elizabeth and Francis was a vessel of some two to three hundred tons with its own ordnance and a cargo of imported salt, gunpowder and arms commissioned by merchants of the town. The attackers intermingled with other boatmen coming with tickets issued by the town's mayor for the ship's cargo of salt. ${ }^{18}$ Taking

14 Thus, while the depositions provide occasional evidence of what life was like for the English at Galway, these were incidental to the focus on the killings - or rather those killings about which the commissioners wanted to hear. Only by chance do we hear of other deaths at Galway not related to these episodes and about which no further evidence was apparently taken. William Hamond mentioned how in the intervening period some of those besieging the fort had seized the wife of a soldier there, stripped and killed her. Of Mrs Johnson we hear no more in the depositions. And only a little more of the three troopers from the fort he also mentioned - Rollright, Percival, and Bennet - hanged by Viscount Clanmorris ('not without most barbarous and inhumane ag[g]ravations of cruelty'), and nothing of the otherwise nameless soldiers from the fort hanged by Redmond Burke whose heads were set upon the walls of the town: Deposition of William Hamond, 14 Aug. 1643, T.C.D., MS 830, ff 134r-134v; Examination of Hiber Scott, 23 Dec. 1653, T.C.D., MS 830 , f. 228 r. William Rollright was probably the husband of another Galway deponent, Margaret Rollright, but testifying as a widow some nine months after his death she makes no reference to his fate in her deposition: Examination of Margaret Rollright, 12 Mar. 1644, T.C.D., MS 830, f. 166r.

${ }^{15}$ Clarke (ed.), 1641 depositions, XII, liv. For Darcy, see Liam O'Malley, 'Patrick Darcy, Galway lawyer and politician, 1598-1668' in Diarmuid Ó Cearbhaill (ed.), Galway town and gown, 1484-1984 (Dublin, 1984), pp 90-109; Aidan Clarke, 'Darcy, Patrick', DIB.

16 [Ulick Burke], The memoirs and letters of Ulick, marquiss of Clanricarde and earl of Saint Albans (London, 1757). For Clanricarde, see Jane Ohlmeyer, 'Burke [de Burgh], Ulick, marquess of Clanricarde (1604-1658)', O.D.N.B.; Aoife Duignan, 'Burke, Ulick (1604-58), 1st marquess of Clanricard', D.I.B.

${ }^{17}$ H.M.C., The manuscripts of the marquis of Ormonde, earl of Fingall, the corporations of Waterford, Galway, etc. (London, 1885), pp 380-520.

${ }_{18}$ According to his widow, one of the boatmen, Brian Roe, at first refused to go and had been locked up overnight: Examination of Margret ni Rory, T.C.D., MS 830, ff 207r-207v. 
advantage of the absence of the captain and with part of the crew ashore gathering ballast, the attackers boarded her under the pretext of helping to unload the salt. ${ }^{19}$

The remnant of the crew was not, however, to be taken unawares. An attempt on the boat had been made the previous day, and it appears that in anticipation of an attack Captain Willoughby, commander at the adjacent fort, had stationed some soldiers aboard to guard the arms and was in the process of sending more. According to the merchant Steven Lynch, some forty townsmen, accompanied by the town's two sheriffs and the captain of the 'company of young men', had attempted to surprise the ship. Thinking the ship already taken, Lynch had gone with a musket to guard it, but those he met coming back had told him that though they had got on board they had been prevented from taking the ship because both the forecastle and lower deck had been barred. ${ }^{20}$ The next day a group of young men, fewer in number - but now armed with swords, skeins [daggers] and pistols - were admitted on board. ${ }^{21}$ Even then, the resort to violence was not immediate.

It was preceded by a series of exchanges in which the would-be attackers sought to exploit the moral norms of sociability and hospitality to secure their objective. On 19 March Dominick Kirwan called to the cabin boy to open the door and when challenged by the ship's surgeon, Robert Rawlins, claimed that he and his friends wanted to share a cup of beer with them in the cabin. Kirwan, whom most deponents identified as one of the leaders of the attackers, had served on this voyage as factor to his brother-in-law Thomas Lynch fitz Andrew, a leading Galway merchant. ${ }^{22}$ In response to Kirwan's offer, the surgeon sent the ship's boy out by the main hatch with beer for them to drink on deck. Kirwan then called Rawlins on deck. Rawlins's subsequent deposition gives no details of their conversation, but its content can be approximated. ${ }^{23}$ According to another deponent, Kirwan had asked to be allowed into the cabin to access his chest. The crew, fearful of surprise, agreed that only he should be admitted. However, once the door was open, two other men, Walter Martin and Murrough ô Moore, forced their entry. ${ }^{24}$ Rawlins, now on deck and seeing that they had got the steerage door open, ran back to the hatch to secure the gun room.

Thomas Martin, another Galway merchant, on deck with the ship's surgeon when what he called the 'uproar' began, described how 'on a sudden' the attackers

Roe was however one of the five men excepted from the Galway 1652 articles of surrender for their part in the murders: Robert Dunlop, Ireland under the Commonwealth being a selection of documents relating to the government of Ireland from 1651 to 1659 (2 vols, Manchester, 1913), i, 164, n.4(4).

${ }_{19}$ Deposition and Information of John Turner, 7 and 23 Mar. 1643/4, T.C.D., MS 830, ff 155r-155v, 146v; Examination of Andrew Darcy, 12 Nov. 1652, T.C.D., MS 830, f. 162r; Examination of Robert Rawlins, 5 Feb. 1653/4, T.C.D., MS 830, ff 197r-198r; Examination of Steven Lynch fitz Andrew, 17 Jan. 1652/3, T.C.D., MS 830, ff 209r-210v; Examination of Dorothy Butler, 21 Mar. 1653/4, T.C.D., MS 830, f. 253v.

${ }^{20}$ Examination of Stephen Lynch, 19 Jan. 1652/3, T.C.D., MS 830, f. 201r; Examination of Hygate Lone, 3 Feb. 1653/4, T.C.D., MS 830, f. 240v; [Burke], Memoirs, pp 99, 100.

${ }^{21}$ Examination of Steven Lynch fitz Andrew, 17 Jan. 1652/3, T.C.D., MS 830, f. 9v. The 1652 articles for the surrender named five men exempted from their terms - Brian Roe, Mahon Moore, Stephen Lynch, Dominick Kirwan and Walter Marten - but the depositions yield almost three times as many names of those alleged to have taken part: T.C.D., MS 830, ff $127 \mathrm{r}-239 \mathrm{v}$, passim.

${ }^{22}$ Examination of Margaret Roche, 9 Mar. 1653/4, T.C.D., MS 830, f. 38r; Examination of Dorothy Butler, 21 Mar. 1653/4, T.C.D., MS 830, f. 252r.

${ }^{23}$ Examination of Robert Rawlins, 5 Feb. 1653/4, T.C.D., MS 830, ff 197v-198r.

${ }^{24}$ Examination of Steven Lynch fitz Andrew, 17 Jan. 1652/3, T.C.D., MS 830, f. 209v. 
fell on the surgeon. ${ }^{25}$ Dangerously wounded in the back, Rawlins was forced to leap into the hold to escape a man stabbing at him with a knife whom Martin claimed to have pushed away. As he was scrabbling to get into the hold, Rawlins was stabbed in the shoulder and forced to hide himself in a cradle between decks. ${ }^{26}$ Martin fled with others into the forecastle to try to hold it against the attackers. According to Rawlins, Herrings, the master's mate, had then called on the ship's gunner to fire from the forecastle to clear the deck, but was stabbed by Murrough ô Moore and died immediately. Other assailants, hearing the noise, then came on board and attacked the crew and soldiers. Walter Martin and Steven Lynch fitz Andrew, another merchant (but not the Steven Lynch cited earlier) ran to the gunroom and overpowered the three crewmen attempting its defence. Those in the forecastle were forced to surrender when the attackers threatened to fire a piece of the ship's ordnance they had set against the door.

Thomas Martin claimed that they were promised good terms if they surrendered, but despite this agreement the attackers threatened to fall on those in the forecastle and he was forced to defend himself, cutting one man with his knife. Several of the crew were wounded and two men were killed, one a soldier sent from the fort. ${ }^{27}$ One man had his head cleft in two, while the other was stabbed in the belly. Mary Bowler, then a young girl, vividly recalled in her testimony how McLaughlin Roe O'Flaherty, one of the attackers, later drinking with other boatmen in her father's house, had clapped his long dagger on the board and boasted that he had killed four of the crew with it. ${ }^{28}$

The violence ended, the remaining crew (one of whom subsequently died from his wounds) and the bodies of the victims were brought into the town. (Another deponent claimed to have heard that the dead were thrown overboard). ${ }^{29}$ On the day of the attack on the ship, the town's gates had been locked and the English had been disarmed and ordered to remain indoors. ${ }^{30}$ Martha Lone, the wife of an officer serving in the fort, claimed that she and other gentlewomen were prevented from attending the wounded ship's surgeon and warned on threat of death not to go to church or market. ${ }^{31}$ But witnesses watched the ship unloaded of all its cargo and moved beyond the range of the fort's guns, which on news of its surprise had fired at

${ }^{25}$ Martin, named in 1653 as one of those involved in the plan to surprise the ship, claimed that he had only been on board to collect his share of the salt but, refusing to sign his deposition, he was committed to prison: Examination of Steven Lynch fitz Andrew, 17 Jan. 1652/3, T.C.D., MS 830, ff 209r-210v; Examination of Thomas Martin, 7 Dec. 1652, T.C.D., MS 830, ff 160r-161r.

${ }^{26}$ Examination of Robert Rawlins, 5 Feb. 1653/4, T.C.D., MS 830, ff $197 \mathrm{v}-198 \mathrm{r}$.

${ }^{27}$ Examination of Thomas Martin, 7 Dec. 1652, T.C.D., MS 830, ff 160v-161r; Deposition of John Sheeley, Magdelin Smith, Margaret Rollright, 25 Mar. 1644, T.C.D., MS 830, ff 168r-169r; Examination of Robert Rawlins, 5 Feb. 1653/4, T.C.D., MS 830, ff 197v-198r; [Burke], Memoirs, p. 126.

${ }^{28}$ Examination of Mary Bowler, 7 Mar. 1653/4, T.C.D., MS 830, ff 245r-245v.

29 Examination of Margaret Rollright, 12 Mar. 1644, T.C.D., MS 830, f. 166r; Deposition of John Sheeley, Magdelin Smith, Margaret Rollright, 25 Mar. 1644, T.C.D., MS 830, ff 168r-169r; Examination of Steven Lynch fitz Andrew, 17 Jan. 1652/3, T.C.D., MS 830, f. 210 r; Examination of Dorothy Butler, 21 Mar. 1653/4, T.C.D., MS 830, f. $253 \mathrm{v}$.

${ }^{30}$ Deposition of Josias Dawson, 27 Oct. 1642, T.C.D., MS 830, f. 128v. Margaret Rollright dated this to the Sunday after Easter, 15 April: T.C.D., MS 830, f. 166r.

${ }^{31}$ Deposition of Josias Dawson, 27 Oct. 1642, T.C.D., MS 830, f. 128v; Examination of Hiber Scott, 23 Dec. 1653, T.C.D., MS 830, ff 227r-227v; Examination of Martha Lone, 23 Feb. 1653/4, T.C.D., MS 830, ff 242r-242v. 
it. The arms, powder and ship's ordnance were removed, and the ship's guns moved through the town and set up against the fort. Later moved to a new harbour, the ship, it was said, was 'broken up by the countrey'. 32

The second episode of violence happened almost a month later. On the afternoon of April 17, the Sunday after Easter, a large contingent of native (Gaelic) Irish of Iar Connacht marched into town. Dressed in their distinctive 'trowse and broages' and armed with swords, pikes and skeans, these 'Cuntry Rebell\{s\}' were said to have come in 'with flyeing colors in hostile Manner' ${ }^{33}$ Lt Hiber Scott, from the fort's garrison, who had been given leave from the mayor to live in the town while sick, later testified that on looking out of the house where he lodged, he saw a tall, swarthy young man, 'one Morrogh ô fflahertie (stiled Collonel) of Ere Coonagh ... Marching downe the streete with about 300 Irish rebells'. ${ }^{34}$ They made a stand near Scott's house, '\& immediately forced into another howse just over the way where about five of those souldjers first stabbed with their skeanes one Mistriss Collins an English gentlewoman whereof she dyed then \& there'. According to Margaret Rollright, in whose house the attack took place, Collins was killed 'as she was kneeling att her praiers'. ${ }^{35}$ After the elderly woman's murder, Scott reported, the Irish 'killd one John ffox a Chandler being an English Protestant by cutting off his head, \& one of them in this Examinants sight brought out his head so cut off, \& by its haire threw it upp'. After it fell to the ground, 'a great Lustie Irish woman tooke it upp by the haire ... \& threw it as high as shee could'. Fox's head was then paraded through the town on the head of a pike to cries of 'there was the head of an English Dogg'. ${ }^{36}$ Later, it was 'tumbled' up and down the streets. According to Margaret Rollright, Fox's head was, 'tossed \& used with very much Disgrace \& kicked like a footeball'. ${ }^{37}$

Fox's wife, otherwise nameless and entering the historical record like others in 1641 only posthumously, ${ }^{38}$ was also killed. William Lincoln, an English maltster, later deposed that it was "the souldiers of ... Captain Bourk [who] moste barbarously cut of the head of Mr John ffox an English man and a protestant, ... and

32 [Burke], Memoirs, p. 9; Deposition of William Hamond, 14 Aug. 1643, T.C.D., MS 830, f. 134r; Depositions of Joseph Turner, 7 Mar. 1643/4, 23 Mar. 1643/4, T.C.D., MS 830, ff 146v, 155r-156r; Examination of John Morgan, 13 Jan. 1653/4, T.C.D., MS 830, f. 229v.

${ }_{33}$ Examination of John Morgan, 13 Jan. 1653/4, T.C.D., MS 830, f. 290r; Examination of Martha Lone, 23 Feb. 1653/4, T.C.D., MS 830, f. 242v; Examination of Richard Butler, 21 Mar. 1653/4, T.C.D., MS 830, f. 255v.

${ }^{34}$ Examination of Hiber Scott, 23 Dec. 1653, T.C.D., MS 830, ff 226v-227r. For O'Flaherty, see M. J. Blake, 'An account of the castle and manor of Bunowen, in the barony of Ballinahinch, county of Galway, and its successive proprietors from the $15^{\text {th }}$ century to the present time' in Galway Arch. Soc. Jn., ii (1902), pp 45-7.

35 Deposition of John Sheeley, Magdelin Smith, Margaret Rollright, 25 Mar. 1644, T.C.D., MS 830, f. 169r; Examination of Margaret Rollright, 12 Mar. 1644, T.C.D., MS 830, f. 166r.

36 Deposition of John Sheeley, Magdelin Smith, Margaret Rollright, 25 Mar. 1644, T.C.D., MS 830, f. 166r; Information of Oliver Smyth, 12 Mar. 1643/4, T.C.D., MS 830, f. 158r; Examination of Ann Hales, 13 Jan. 1653/4, T.C.D., MS 830, f. $233 \mathrm{v}$.

${ }^{37}$ Deposition of John Sheeley, Magdelin Smith, Margaret Rollright, 25 Mar. 1644, T.C.D., MS 830, f. 169r.

${ }^{38}$ On lives lived outside the 'identity-confirming realm of public record', see Patricia Palmer, 'Fugitive identities: selves, narratives and disregarded lives in early modern Ireland' in Eve Campbell, Elizabeth Fitzpatrick and Audrey Horning (eds), Becoming and belonging in Ireland $A D$ c.1200-1600: essays in identity and cultural practice (Cork, 2018), pp 313-27, at p. 316. 
then and there murthered ... Mr ffoxes wife'. According to Magdalene Smith, Mrs Fox, being dangerously wounded, 'the preists and fryers [had] resorted to her to seduce and convert her[,] but not prevaileing that wicked rebell that had wounded her before, then murthered her outright'. An officer in the fort, Hygate Lone, testified that he had heard from his wife and mother-in-law and others who were then in the town, that Mrs Fox was also decapitated and her head subjected to similar treatment. John Turner too reported that the rebels 'tumbled' both the heads of John Fox and his wife 'about the streets'. Others staying in the same house were also killed, including the ship's carpenter who had been wounded on the Elizabeth and Francis. ${ }^{39}$ So too was 'a yong gallant yowth', the twelve-year-old son of $\mathrm{Mr}$ Fisher, one of the English refugees who had fled from Tuam to Galway.

Groups of rebels were described as rushing up and down the town's streets. Twenty or thirty of them entered the house where Lt Scott lodged. Scott claimed to have had a narrow escape, breaking a window and clambering over the rooftops. But as he was escaping he had heard Mistress Harding, the wife of an English minister, her sister Mistress Scott (his brother's wife) and another woman, 'drawne downe the sta[i]res whoe pitifully stritched [screeched] becawse of the barbarous usage then exercised upon them'. As he later deposed, his brother's wife died shortly thereafter from her injuries. Scott, whose escape ended in capture and imprisonment the next day, recounted that he had had to share his prison with a 'barbarous bloody Rebell' who, overtaken with drink, had 'bragged how he had kild an English woman, \& what good it had done him to see her child sprawle after he had ript it out of her wombe'. 40

Hearsay might add to the numbers killed. Martha Lone, after listing the Foxes and Mrs Collins as victims, said that she had heard of several other English then murdered, but testified that she could say no more since she 'was then sick in her bed'. Oliver Smyth, after reporting the deaths of the Foxes, Mrs Collins and Fisher's son, included, but did not name, 'others, English protestants'. William Lincoln reported that the soldiers had killed 'two English women more'. One was presumably Mrs Collins; the other he named as 'sister to Lieutenant Stapleton'. No other deponent mentions this death, but since the report may be doubtful it might represent some confusion with the fate of Lt Scott's brother's wife. Nor did any other deponent mention the glover's wife, whose death Dorothy Butler included in those who died subsequently of their wounds. But neither did she in her deposition mention the 'suckling child' that her husband included in his list of those murdered. ${ }^{41}$ William Lincoln ended his list of those killed with the claim that 'they alsoe murthered diuers others of th[e] english whom he cannot name', while another group of English deponents who had continued to live under threats in the town before finally fleeing to the fort, claimed

${ }^{39}$ Deposition of William Lincoln, 14 Jan. 1644/5, T.C.D., MS 830, f. 142r; Examination of Hygate Lone, 3 Feb. 1653/4, T.C.D., MS 830, f. 241v; Deposition of Joseph Turner, 23 Mar. 1643/4, T.C.D., MS 830, ff 146v-147r; Deposition of Oliver Smyth, 12 Mar. 1643/4, T.C.D., MS 830, f. 158r; Deposition of John Sheeley, Magdelin Smith, Margaret Rollright, 25 Mar. 1644, T.C.D., MS 830, f. 169r; Examination of Margaret Roche, 9 Mar. 1653/4, T.C.D., MS 830, f. 238v; Examination of Jane Shelley, 25 Jan. 1653/4, T.C.D., MS 830, ff 247r-247v; Examination of Dorothy Butler, 21 Mar. 1653/4, T.C.D., MS 830, f. 254r.

${ }^{40}$ Examination of Hiber Scott, 23 Dec. 1653, T.C.D., MS 830, ff 226v- 227r.

${ }^{41}$ Deposition of William Lincoln, 14 Jan. 1644/5, T.C.D., MS 830, f. 142r; Examination of Robert Rawlins, 5 Feb. 1653/4, T.C.D., MS 830, ff 198r; 254r; Examinations of Dorothy and Richard Butler, 21 Mar. 1653/4, T.C.D., MS 830, f. 256r. 
more wildly that the rebels had subsequently murdered most of those who stayed. ${ }^{42}$

The killings were followed by the plundering of the English in the town. Guided sometimes, it would appear, by townsmen, groups then broke into other houses with English occupants. A merchant's wife, Margaret Roch, deposed 'that about the tyme of the saith murther the Comon sort of Irish in the towne plundered many English'. ${ }^{43}$ John Goll, a soldier then in the fort, deposed that William oge Martin brought ten or more of the O'Flahertys into his house and plundered him. Michael Smyth, archdeacon of Clonfert, reported that his house too was assaulted. At Margaret Rollright's house, the Irish, having killed Mrs Collins, then disarmed all the English and robbed her. ${ }^{44}$ That same night, Dorothy Butler and her husband, a Protestant minister, had their house invaded and were forced to hide from those whom she feared intended their murder and who went on to rifle all their goods. To judge by the names she gave these were townsmen of Galway; included in their number was William Noone, the corporation's swordbearer. ${ }^{45}$

Protestant deponents believed that there was an intention to murder all the English and that the O'Flahertys were brought in by the town and corporation to do so. But their depositions suggest a more complex reality. Although she made no reference to it in her own deposition, Captain Lone testified that his wife and mother-in-law 'hardly escaped murthering' and reported 'that hee credibly heard by them (and other English) that the townsmen had given consent to the murthering of all the English', but 'the priest and ffryers went upp and downe the streets and hindered the murthering of any more of them'. Others echoed this. Lt Goll reported 'that it was commonly spoken in Galway that the said o fflahertyes of Irconnaght were brought into the towne purposely to murther all the English. And he beleiveth that they had murthered them all accordingly had not', he too acknowledged, 'some preists hindered them, by goeing out in their vestments with tapers and a Crucifix carried before them, commanding the said murtherers to surcease'. ${ }^{46}$ The servant Mary Bowler as a young girl not only saw what happened, but also heard what was said. Her testimony in Irish, 'taken by the Interpretacion of lieuetenant Jull [Goll] upon his oath', challenges the simple lines of conflict drawn by the English deponents. Bowler testified that she had seen,

the Preists of the Towne \& other Preists (being about eight in number) goeing about the Towne in their vestments, with tapers lighted burneing, and the Sacrament borne before them, and earnestly exhorting the said Murrough

${ }^{42}$ Examination of Martha Lone, 23 Feb. 1653/4, T.C.D., MS 830, f. 242r; Deposition of William Lincoln, 14 Jan. 1644/5, T.C.D., MS 830, f. 142r; Information of Michael Smyth, 11 Mar. 1643/4, T.C.D., MS 830, f. 151r; Deposition of John Sheeley, Magdelin Smith, Margaret Rollright, 25 Mar. 1644, T.C.D., MS 830, f. 169r.

43 Examination of Margaret Roche, 9 Mar. 1653/4, T.C.D., MS 830, f. 238r. However, one deponent claimed that her principal robber was her landlord, the merchant Thomas Burke: Deposition of John Sheeley, Magdelin Smith, Margaret Rollright, 25 Mar. 1644, T.C.D., MS 830 , f. $169 \mathrm{v}$.

44 Examination of Lt John Goll, 7 Mar. 1653/4, T.C.D., MS 830, f. 244r; Information of Michael Smyth, 11 Mar. 1643/4, T.C.D., MS 830, f. 151r; Deposition of Magdalene Smith, 25 Mar. 1644, T.C.D., MS 830, f. 169r.

${ }^{45}$ Examinations of Dorothy and Richard Butler, 21 Mar. 1653/4, T.C.D., MS 830, ff 254v, $256 \mathrm{r}$.

${ }^{46}$ Examination of Hygate Lone, 3 Feb. 1653/4, T.C.D., MS 830, f. 241v; Examination of Lt John Goll, 7 Mar. 1653/4, T.C.D., MS 830, f. 244r. 
ne mart and his Company for Christs sake, and our ladyes, and St Patricks, that they wold shed noe more blood, for if they did they wold never have mercy.

She too is reported as saying that 'she verily beleveth that had it not bin for the said Preists the said o fflahertyes and their Company had killed all the English protestants they had found in Galwaye'. ${ }^{47}$ Some townsmen, including leading members of the town's ruling group, had also opposed the violence. The English minister, Richard Butler, believed that there would have been 'a total massacre of all the English Protestants in the towne that night' but for the Franciscan friars and 'some of the townes men that were very active in resisting the murtherers'. Margaret Roch vividly recalled seeing Sir Thomas Blake, an alderman and former mayor, chase and capture an Irish rebel, 'running with a drawne skeane, and his Armes all bloody'. 48

The ubiquity of the insult 'English dog' that was hurled at Lt Scott (in Irish) by his pursuers, ${ }^{49}$ at the ship's surgeon by Dominick Kirwan and at John Fox's head as it was paraded through the streets reflected the popular hostility that lay behind the killing of the English. A small group of Protestants later deposed that,

they durst not goe out neither night nor day without danger of their lives (being subject every day to their scandalls and op[p]robrious words as English dogs, and threatening often by what death the English dogs ... should suffer death ... Their very frie or yonge base children would ... come to the English women \& say ... with their skeanes presented, you English Jades or dogs I will cut your throats. ${ }^{50}$

The English plasterer, David Lawson, later deposed that he was not able to name any of those involved in the attack on the ship because he and all the English in Galway were 'in soe much danger and feare that the[y] durst not stirre out of their lodgings for feare of being killed by the Irish'. 51

On the day before the attack on the ship, the English found themselves on leaving church surrounded by 'rude \& deboist [debauched] Irish soldiers' and forced to subscribe an oath to be true to king and town. ${ }^{52}$ Subsequently, they were summoned before the mayor and Council of Eight, newly appointed to oversee the town's security, and again required to take an oath 'to be true to them and to the towne'. ${ }^{3}$ And before 10 March (and perhaps again in April), the English were required to sign a certificate 'purportinge the good demeanour \& carriage' of the townsmen towards them ('as in case we had been of their own flesh and blood'). Some believed that refusal would have resulted in 'some suddaine hurt or

47 Examination of Mary Bowler, 7 Mar. 1653/4, T.C.D., MS 830, ff 245v-246r.

48 Examination of Richard Butler, 21 Mar. 1653/4, T.C.D., MS 830, f. 256r; Examination of Margaret Roche, 9 Mar. 1653/4, T.C.D., MS 830, f. 238v.

49 Examination of Hiber Scott, 23 Dec. 1653, T.C.D., MS 830, f. 226v.

50 Deposition of John Sheeley, Magdelin Smith, Margaret Rollright, 25 Mar. 1644, T.C.D., MS 830, f. 169r.

51 Examination of David Lawson, 21 Mar. 1653/4, T.C.D., MS 830, ff 257r-257v.

52 Deposition of John Sheeley, Magdelin Smith, Margaret Rollright, 25 Mar. 1644, T.C.D., MS 830, f. 168r. These deponents give the date as $18 \mathrm{March}$, but refer to the Sunday next before St Patrick's Day, which in 1642 was 14 March.

${ }^{53}$ Deposition of Oliver Smyth, 12 Mar. 1643/4, T.C.D., MS 830, f. 158r. 
mischiefe'; Clanricarde suggested that the fulsome declaration the English had signed before the killings was 'to give them more safety, they having been sometimes frightened by unruly people who were not duly punished. ${ }^{54}$

By spring 1642, refugees fleeing violence elsewhere had increased the number of English in the town to some 400 or more. ${ }^{55}$ Clanricarde attributed demands for the disarming of the English and for the closure of the churches and prohibition of Protestant worship after the 19 March episode to 'discourse amongst the unruly multitude' ${ }^{56}$ The mayor claimed that they had been disarmed to prevent any in the town that might have drawn a 'great inconveniency' on them. But that in justification of this policy he also cited 'the example of the like usage to catholicks' at Dublin, Cork and and Youghall 'whose present miserable condition did put us in mind of what we were to expect' suggests that even the corporation shared these popular anxieties. ${ }^{57}$ It is perhaps an indication of the tensions in the town that when Lt Scott was captured during the violent April episode and brought before the mayor and others from the Council of Eight, he was interrogated as to "whether he was sent to burne the towne or noe'? That the Irishman with whom Scott had been forced to share his imprisonment was allowed to keep his arms in prison and, after receiving 'many visits of the townsmen' overnight, was let out the next day suggests some disagreement in the town as to whether his actions merited condemnation or congratulation. ${ }^{58}$

\section{III}

There was a consensus among English deponents about the causes and character of the violence at Galway. Predictably, as the language recorded in their depositions suggests, the seizure of the ship was the product of Irish treachery and the killing of Fox and others confirmation of the barbarity with which English commentators had long associated the native Irish. ${ }^{59}$ Thus, the ship was 'treacherously' taken, its crew 'barbarously' murdered. John Fox was murdered in 'a barbarous inhumane manner', being 'most barbarously' decapitated, and English women at Galway subjected to 'barbarous usage'. The perpetrators were 'Ruffian irish barbarous souldjers', the 'rude \& barbarous multitude of Rebells of EreConnaght', and their actions 'barbarous Cruelties'. ${ }^{60}$ But behind this parade of familiar prejudices

${ }^{54}$ Information of Michael Smyth, 11 Mar. 1643/4, T.C.D., MS 830, f. 151r; [Burke], Memoirs, pp 85-6 (my emphasis).

${ }_{56}^{55}$ [Burke], Memoirs, pp 132, 141.

56 Ibid., pp 139, 140

57 Ibid., pp 100-01.

${ }^{58}$ Examination of Hiber Scott, 23 Dec. 1653, T.C.D., MS 830, f. 227 r.

${ }^{59}$ Kathleen Noonan, "The cruel pressure of an enraged, barbarous people": Irish and English identity in seventeenth-century policy and propaganda' in Historical Journal, xli, no. 1 (1998), pp 151-77; eadem, "Martyrs in Flames": Sir John Temple and the conception of the Irish in English martyrologies' in Albion, xxxvi, no. 2 (2004), pp 223-55; Jane Ohlmeyer, 'Civilizing of those rude partes: colonization in Britain and Ireland, 1580s1640s' in Nicholas Canny (ed.), The origins of empire: British overseas enterprise to the close of the seventeenth century (Oxford, 1998), p. 131; Joseph Cope, 'Fashioning victims: Dr Henry Jones and the plight of Irish Protestants, 1642' in Historical Research, lxxiv, no. 186 (2001), pp 370-91.

${ }^{60}$ Deposition of Josias Dawson, 27 Oct. 1642, T.C.D., MS 830, f. 128r; Deposition of William Hamond, 14 Aug. 1643, T.C.D., MS 830, f. 134v; Examination of Margaret 
was an attempt to blame Galway's Old English rulers for the violence. As Lt Goll reported, the O'Flahertys came 'by procurement of the magistrates of the towne'. ${ }^{61}$ Inadvertently, however, these claims reveal the prolonged negotiations and complex politics that had preceded and were to follow the violence.

It was only after the failure of negotiations that an attempt was made on the Elizabeth and Francis. When the arms' removal was stayed after the ship's arrival by a warrant from the Dublin administration to the earl of Clanricarde to impound and deliver them to the fort, the town attempted to secure their release. Kirwan was heard to say that he had brought arms and ammunition for the town's use, but Captain Clarke gave notice of the arms to Anthony Willoughby, commander, and John Turner, collector of customs at Galway and clerk of the store at the fort. This was probably the occasion of the heated on-board exchange between Captain Clarke and Dominick Kirwan, witnessed by Dorothy Butler when she went to inspect a cabin for her travel to France. Being 'at very high words', Clarke, she reported, threatened that 'if Kirowan had spoken a little more to him hee wold have thrown him overboard'. ${ }^{2}$

Before the ship's capture, Turner and Clarke had been called before a General Assembly of the town and temporarily imprisoned. In the interim, Sir Valentine Blake and Nicholas Bodkin, merchants and members of the corporation, the latter later described as captain, had apparently been authorised to offer to buy the ship and her guns to strengthen the town's defences. Clarke was offered eleven hundred pounds for the ship's ordnance, but asked for more time. According to James Lynch fitz Stephen, examined when later a prisoner, they were 'allmost agreed' but Clarke sent a message that he would not sell the ship at any price. A day or so later, a group of townsmen went to see Blake in his chamber. When told that the bargain was broken off, one of those present, Thomas Lynch fitz Andrew was reported as saying, 'I can tell yow a good Way to ffasten the bargaine upon Captain Clarke'. He proposed hiring some of the commons and young men of the town to secure the ship so that Clarke 'would be Glad to take Mony' for it. Blake initially agreed, but by the next day was reported to have changed his mind. ${ }^{63}$

Evidently, there were fears that the ship would join with the town against the fort. ${ }^{64}$ Clearly, the corporation was trying to find a way to secure its defences that avoided violence, but the proposal from Lynch, younger and not an officeholder in the town, suggests a hardening of opinion, perhaps inside, and certainly outside, the town's ruling circle. The reported presence of the town's two sheriffs and the involvement of a group with responsibility for 'watch and ward' in the town, the 'young men', in the initial attempt to take back the arms might be taken to indicate a semi-official move by the town to reclaim the arms. But

Rollright, 12 Mar. 1644, T.C.D., MS 830, f. 166r; Examination of Dorothy Butler, 21 Mar. 1653/4, T.C.D., MS 830, f. 254r; Deposition of William Lincoln, 14 Jan. 1644/5, T.C.D., MS 830, f. 142r; Examination of Hiber Scott, 23 Dec. 1653, T.C.D., MS 830, f. 226v; Deposition of John Sheeley, Magdelin Smith, Margaret Rollright, 25 Mar. 1644, T.C.D., MS 830, ff $168 \mathrm{v}, 169 \mathrm{v}$; Information of Joseph Turner, 7 Mar. 1643/4, T.C.D., MS 830, f. 156r.

${ }^{61}$ Examination of Lt John Goll, 7 Mar. 1653/4, T.C.D., MS 830, f. 244r.

${ }^{62}$ Examination of Dorothy Butler, 21 Mar. 1653/4, T.C.D., MS 830, f. 254r.

${ }^{63}$ Examination of Andrew Darcy, 12 Nov. 1652, T.C.D., MS 830, f. 162r; Examination of Steven Lynch fitz Andrew, 17 Jan. 1652/3, T.C.D., MS 830, f. 209r; Examination of James Lynch fitz Stephen, 20 Jan. 1652/3, T.C.D., MS 830, ff 164r-164v.

${ }^{64}$ Examination of Stephen Lynch, 19 Jan. 1652/3, T.C.D., MS 830, f. 201r; Examination of Mary Bowler, 7 Mar. 1653/4, T.C.D., MS 830, f. 245. 
significantly, when the successful attempt was made to seize the ship it was by those not part of the ruling group. Even then it was a few days later, and after a failed attempt undertaken on a promise from the Council of Eight that they would 'save the undertakers harmless[s]', that the ship was violently taken. ${ }^{65}$

New English deponents, many of whom were refugees from the surrounding countryside, were of course not privy to these discussions, conducted at the mayor's or another private house, nor to the meetings at the town hall. But they recounted what others told them. Martha Lone deposed that, "she cold somtymes heare the Irish telling [in Irish] in the streets ... that they did nothing but what they had order for from the Maior and Patricke Darcy and the Aldermen and beste of the towne'. ${ }^{66}$ Convincing evidence of the town rulers' central role in the violence, it was repeatedly alleged, was provided by their inactivity after the violence. According to several deponents, they 'did not in any way punish the offenders, but rather abetted and maintained them in their barbarous cruelties'. Of the killing of Fox and others, William Hamond claimed that 'the Towne pleaded not guilty ... but thus farre they must needs be faulty, that the agents were entertained \& let into the Towne by them, nor did they ever after ... [that he heard] make any enquiry after or punish' them. ${ }^{67}$ They had invited in the O'Flahertys with promises of pay and plunder in return for killing the English. ${ }^{68}$ As the native speaker, Mary Bowler, testified, she had 'heard (by severall of the towne people) that it was the Maior and Councell of the towne that had brought in the said Irconnaght people to kill and murther all the English Protestants in the towne because their owne hands should not be embrued in their blood'. ${ }^{9}$

It was therefore, the depositions suggested, the town's 'Cheife Governors' who were ultimately to blame for the violence in $1642 .{ }^{70}$ Both the examiners and the New English witnesses agreed that the townsmen were rebels and that the events at Galway in early 1642 constituted a rebellion. Significantly, the 1652 treaty on the final surrender of Galway dated the town's joining the rising to 19 March 1642 , the date of the attack on the ship. But reading against the grain of the otherwise stereotyped accusations of the witnesses, there is evidence to challenge and complicate the picture that the deponents and their examiners sought to paint. Framing the depositions in terms of a binary divide between English victims and violent Irish rebels ignores evidence contained in the depositions (and confirmed in other valuable sources) that reveals the divisions within the town over the use

65 Examination of Stephen Lynch, 19 Jan. 1652/3, T. C. D.T.C.D., MS 830, f. 201r.

${ }^{66}$ Examination of Martha Lone, 23 Feb. 1653/4, T.C.D., MS 830, f. 242v.

${ }^{67}$ Deposition of Joseph Turner, 23 Mar. 1643/4, T.C.D., MS 830, f. 147r; Examination of Margaret Rollright, 12 Mar. 1644, T.C.D., MS 830, f. 166r; Deposition of William Hamond, 14 Aug. 1643, T.C.D., MS 830, f. 134r; Information of Michael Smyth, 11 Mar. 1643/4, T.C.D., MS 830, f. 151r.

${ }_{68}$ Examination of Margaret Rollright, 12 Mar. 1644, T.C.D., MS 830, f. 166r; Examination of Hiber Scott, 23 Dec. 1653, T.C.D., MS 830, f. 227v; Examination of Hygate Lone, 3 Feb. 1653/4, T.C.D., MS 830, f. 241v; Deposition of Jane Shelley, 25 Jan. 1653/4, T.C.D., MS 830, f. $247 \mathrm{v}$.

${ }^{69}$ Examination of Mary Bowler, 7 Mar. 1653/4, T.C.D., MS 830, f. 245v.

${ }^{70}$ Information of Michael Smyth, 11 Mar. 1643/4, T.C.D., MS 830, f. 152r. 
of violence. If the investigations were designed to show that events at Galway were part of the wider rising, they also reveal that within Galway they were part of a challenge to existing political structures and culture. Though the potential radicalism within that challenge ultimately failed, it drew on the politicisation inherent in reactions to the policies of anglicisation and Protestantisation pursued by the English administration in a town with developed structures of self-government, a sophisticated political culture and a resilient Catholic church, locally strongly present. Thus, the violence in Galway was a product of political division (with its roots partly in class and ethnic difference), but also of a political alliance that reflected shifting attitudes within the town in response to the crisis of 1641 and the actions of the English pro-parliamentary authorities, centred locally in 1641-2 on the question of arms, the fort and civic independence.

A regional capital, with a population of over 4,000 in 1600, Galway dominated its extensive rural hinterland, in which the townsmen were major landowners, and it derived much of its wealth from continental trade. ${ }^{71}$ The town was controlled by a wealthy merchant elite and ruled by a small, self-selecting merchant oligarchy, with leading offices in the first half of the seventeenth century filled by only fourteen families. These families, the so-called tribes of Galway, represented the dominance of trade and town by the Old English, pre-Reformation settlers. Almost without exception, they remained committed to a resurgent Catholic church. This benefitted from their patronage, and was served by secular and regular clergy recruited from their ranks, who with the town's involvement in international trade were educated on the continent in Counter-Reformation thinking. ${ }^{72}$ Knitted together by ties of landownership, trade, ethnicity and inter-marriage, Galway's mercantile rulers formed a close-knit patriciate for whom a commitment to a corporate Catholicism came, under state interference, to stand as the culture of civic independence (joyfully celebrated and formally recorded both by the corporation and town's annals, in the public restoration of Mass in the town's churches after 1642). ${ }^{73}$

${ }^{71}$ R. A. Butlin, 'Irish towns in the sixteenth and seventeenth centuries' in Butlin (ed.), The development of the English town (London, 1977), p. 93; Anthony Sheehan, 'Irish towns in a period of change 1558-1625' in Ciaran Brady and Raymond Gillespie (eds), Natives and newcomers: the making of Irish colonial society 1534-1641 (Dublin, 1986), pp 93-119.

72 Brendan Bradshaw, 'The reformation in the cities: Cork, Limerick and Galway, 15341603 ' in John Bradley (ed.), Settlement and society in medieval Ireland (Kilkenny, 1988), pp 445-76; Thomas Connors, 'Religion and the laity in early modern Galway' in Gerard Moran and Raymond Gillespie (eds), Galway: history and society. Interdisciplinary essays on the history of an Irish county (Dublin, 1996), pp 130-48; Bernadette Cunningham, 'Nuns and their networks in early modern Galway' in Salvador Ryan and Clodagh Tait (eds), Religion and politics in urban Ireland, c.1500-c.1700 (Dublin, 2016), pp 156-72; Hugh Fenning, 'The Dominicans of Galway, 1488-1988' in Eustás Ó Héideá (ed.), The Dominicans of Galway, 1231-1991 (Galway, 1991).

${ }^{73}$ Bríd McGrath, 'Managing the Windsor of Ireland: the composition of Galway town council, 1603-1653' in Galway. Arch. Soc. Jn., lxix (2017), pp 61-81; H.M.C., Manuscripts of ... the corporations of Waterford, Galway, etc., p. 492; Paul Walsh, 'An account of the town of Galway (T.C.D., MS 886)' in Galway. Arch. Soc. Jn., xliv (1992), pp 72-3. On the link between Catholicism and corporateness, see the stimulating body of work by Colm Lennon: The lords of Dublin in the age of Reformation (Dublin, 1989); 'Civic power and state power in Dublin 1543-1613' in Rostrum: a Journal of Education and the Arts (1987), pp 107-13; 'Fraternity and community in early modern Dublin' in Robert Armstrong and Tadhg Ó hAnnracháin (eds), Communities in early modern Ireland (Dublin, 2006), pp 167-78. 
Self-government had been granted to Galway by royal charter. A succession of royal charters underwrote the city's political independence and economic prosperity, giving the city valuable exemptions from taxes on trade and from political interference by the provincial presidency. ${ }^{74}$ Royal incorporation informed the town's recurring stress on its long tradition of loyalty to the crown. ${ }^{75}$ This allegiance was powerfully underwritten by the ruling Old English elite's self-identity as English. It bound them to the Crown and with their claim to civility — as 'a modest and civil people', 'not following the customs of the mountainous and wild people of those parts ${ }^{76}$ - distinguished them from the native (Gaelic) Irish. ${ }^{77}$ As a draft petition of the town's inhabitants from 1655 proclaimed, they had 'for upward of four hundred years performed the English interest in this corporation, not withstanding the several rebellions in this nation, till the late general defection'. ${ }^{78}$ Wealthy and self-governing (and at some distance from the English administration in the Pale), the town's merchants might well merit their later description as 'princes' and Galway the title of city-state or 'virtual city-republic by royal charter'. ${ }^{79}$ But civic independence by chartered privilege had its limits and Galway's allegiance was conditional. From the early seventeenth century on, Galway's rulers were to discover the insecurities of their liberties. ${ }^{80}$

Before 1641, renewed emphasis on the requirement for all officers to take the oath of supremacy - in Galway for the mayoralty publicly at the head of the church $^{81}$ - had disrupted the cursus honorum of civic office and led periodically to the imposition of Protestants as mayor. ${ }^{82}$ As with other towns, the stationing of troops in Galway at St Augustine's fort, built to command the town as well as the bay, had also created conflict that had intensified immediately before the outbreak of violence. ${ }^{83}$ In the 1630 s, Wentworth's policies as Lord Deputy posed a particular threat. With their increasingly heavy investment in land, Galway's mercantile elite had been unsettled by the crown's failure to ratify their late sixteenth-century composition made under the crown's policy of surrender and regrant. But Wentworth's proposed plantation in Connacht, which would have confiscated half of every holding above 134 acres and all of the holdings below that figure, represented an even

${ }^{74}$ James Hardiman, The history of the town and country of the town of Galway from the earliest period to the present time (Dublin, 1820), pp 99, 102.

${ }_{75}$ M. D. O'Sullivan, Old Galway: the history of a Norman city in Ireland (Cambridge, 1942), p. 197.

76 Jacinta Prunty and Paul Walsh, Gaillimh/Galway, Irish Historical Town Atlas, no. 28 (Dublin, 2016), p. 2.

77 Joseph Mannion, 'Elizabethan County Galway: the origin and evolution of an administrative unit of Tudor local government' in Galway Arch. Soc. Jn., lxiv (2012), pp 64-89; Mary O’Dowd 'Gaelic economy and society' in Brady \& Gillespie, Natives \& newcomers, p. 131.

78 John Cunningham, Conquest and land in Ireland: the transplantation to Connacht, 1649-1680 (Woodbridge, 2011), pp 91-2.

79 Ibid., p. 93; Seán Keane, 'The Irish city-state: a case study of Galway' in The History Review, xiii (2002), pp 142-50; Bradshaw, 'Reformation in the cities', p. 447.

${ }^{80}$ Nicholas Canny, 'Galway: from the Reformation to the Penal Laws' in Ó Cearbhaill (ed), Galway town and gown, pp 10-28.

${ }^{81}$ Walsh, 'Account of the town of Galway', p. 71.

${ }^{82}$ McGrath, 'Managing the Windsor of Ireland', pp 65-70; O'Sullivan, Old Galway, p. 168.

83 John Towler, 'The transformation of Galway: an urban history of a port town 1600 1700 ' (Ph.D. thesis, Galway-Mayo Institute of Technology, 2012), pp 63-7; [Burke], Memoirs, pp 81-2. 
greater threat. It was, of course, also a threat to the O'Flahertys of Iar Connacht. Given the potential loss of up to four-fifths of its citizens' land, Galway was heavily implicated in the fierce resistance to Wentworth's scheme. This saw the jury that failed to find for the Crown imprisoned and heavily fined, while the corporation's lawyers representing the landowners, Patrick Darcy and Richard Martin, were barred from practising law. ${ }^{84}$ Challenged too was the town's Old English rulers' construction of themselves as loyal Englishmen. As a later document complained, the policy had been conducted 'without consideration of being English or Irish extraction'. It was significant, it has been suggested, that in direct response members of Galway's ruling families had begun to adopt multiple patronymics to assert their ancestry in the town. ${ }^{85}$

When Captain Clarke and John Turner had been examined before the seizure of the ship at a meeting of the Court of Assembly, the town's legal counsel, Patrick Darcy and Richard Martin, condemned their detaining arms imported for the town's defence to be treason. The sparse evidence suggests that behind this claim - as Turner noted, 'they then pretending themselves to be his Maiesties subjects' — was a familiar appeal to Galway's long record of independence and loyalty to the crown. ${ }^{86}$ As the document drawn up by Corporation on 12 March declared, only a week before the attack on the Elizabeth and Francis, they were the king's 'most humble, faithful, and loving subjects'. Calling to mind the 'fast fidelity' of 'this ancient English colony' to the English crown, the declaration reiterated their 'natural obedience \& allegiance', and re-stated their commitment to defend town and fort (but with the proviso of the fort complying with them) against any traitorous conspiracies. They also made an offer to take the oath of allegiance throughout the town and to expel any who refused to take it. ${ }^{87}$ But only three days later the Elizabeth and Francis was seized.

State interference and the consequences and costs of anglicisation had challenged Galway's self-identification as loyal subjects of a Protestant English crown. Writing to Clanricarde two days after the ship's seizure, the town's mayor, Walter Lynch, informed him that the refusal to take money for the arms 'did administer occasion to divers to believe that a hard opinion was undeservedly conceived of our loyalty'. Reports of the seizure of Galway shipping at Dublin and in England had created fears in the town that 'there was but very little distinction made between us and enemies'. With rumours flying, rebels active in the province and relations fraying between the fort and a town, the mayor had repeatedly complained of the great want of arms and ammunition. ${ }^{88}$ Clanricarde, his own loyalty compromised by his Catholicism in the eyes of the Dublin authorities, had been unable to secure a supply of arms for the town or to persuade Captain Willoughby (a man whom he found 'of a rash, violent nature' and in 'temper nor judgement' unfit to command the fort) to accede to the town's repeated request

${ }^{84}$ Aoife Duignan, 'The implications of Thomas Wentworth's proposal for a plantation in Connacht and the provincial Old English' in The History Review, xii (2001), pp 26-9; Aidan Clarke, The Old English in Ireland 1625-42 (Dublin, 1966), pp 100-07; Bernadette Cunningham, Clanricard and Thomond, 1540-1640: provincial politics and society transformed, pp 59-63; McGrath, 'Managing the Windsor of Ireland', pp 72-3; Hardiman, History, pp 104-05.

${ }^{85}$ H.M.C., Report on Franciscan manuscripts preserved at the convent, Merchants' Quay, Dublin (Dublin, 1906), p. 241; McGrath, 'Managing the Windsor of Ireland', p. 73.

${ }^{86}$ Deposition of Joseph Turner, 23 Mar. 1643/4, T.C.D., MS 830, f. 146v.

${ }^{87}$ [Burke], Memoirs, pp 92-3.

88 Ibid., pp 100, 10-11, 16, 40-41. 
to supply them with arms. ${ }^{89}$ Galway's rulers thus found themselves caught between Willoughby's aggressive proto-parliamentarianism and the Dublin administration's continuing failure to provide arms for those whose Catholicism - they believed made their loyalty questionable. They had sought to align their actions within a culture of allegiance to the crown, claiming justification for their taking of the arms in an appeal to what they called the late proclamation requiring communities to acquire arms for their defence against the rising. ${ }^{90}$ Although distancing himself from the violence and (ambiguously) attributing it only to 'some in the town', the mayor had stressed that it was finding themselves in the 'extremity' of lacking arms for their defence that had led to the ship's seizure. Thus, the unsuccessful attempt to take the ship on 18 March, with a crowd that included the corporation's two sheriffs and members of the company of young men, might be read as a quasi-official intervention. ${ }^{91} \mathrm{~A}$ group with its own officers and by-laws and recognised by the corporation as 'a body politic of themselves' with responsibility for watch and ward, the involvement of the company of young men, paralleling similar interventions in other cities, in the attempted seizure was to be significant. ${ }^{92}$ Their accountability for security in the town was to lead them to challenge the existing structures of rule in Galway, and to claim a larger role in civic government during and after the episodes of violence. ${ }^{93}$

Threatened too by the policy of Protestantisation was the commitment to the Catholic faith central to Galway's rulers' self-identity. In a submission to Clanricarde in May 1642 signed by the mayor and four others, what were euphemistically called the 'troubles' in the town were attributed to 'an apprehension taken upon report of ruin \& destruction threatened to the nation, and Catholic religion'. 94 A year later, during negotiations for a truce, the town submitted another paper entitled 'Some Particular Motives of these troubles in Ireland' which repeated this analysis. The paper made defence of the true religion its opening clause and saw all other grievances as stemming from the attempt to supplant Catholicism with Protestantism. It raised again the refusal to arm the town ('and what good meaning was thereby intended, every indifferent man may judge'), referred to the fate of fellow Catholics, disarmed and plundered, in Dublin, Cork and Youghal, and complained of the seizure of ships, goods and persons, 'under colour of a quarrel to their religion'. Dominick Kirwan, the leader of those who attacked the Elizabeth and Francis, was reported to have demanded in his exchange with Robert Rawlins, 'whether it were not better to be a slave in Argere [Algiers] than there'? ${ }^{95}$

The thrust of the evidence offered in the depositions and examinations was that the corporation was behind the seizure of the ship and the invitation to the

${ }^{89}$ Ibid., pp 61, 65, 72, 96.

90 Ibid., p. 127.

${ }^{91}$ Stephen Lynch claimed that he would not have joined had not the Council of Eight authorised the attempted seizure and the mayor promised to save them harmless: Examination of Stephen Lynch, 19 Jan. 1652/3, T.C.D., MS 830, f. 201r.

92 Examination of Stephen Lynch, 19 Jan. 1652/3, T.C.D., MS 830, f. 201r; Examination of Steven Lynch fitz Andrew, 17 Jan. 1652/3, T.C.D., MS 830, f. 210r. The role of young men in the revolt at Waterford is the subject of a further essay in preparation.

${ }^{93}$ Walsh, 'An account of the town of Galway', pp 62, 70.

94 [Burke], Memoirs, p. 135.

95 Examination of Robert Rawlins, 5 Feb. 1653/4, T.C.D., MS 830, f. 197r. 
O'Flahertys. But although the evidence is problematic, given the (deliberate?) silence in the town's records, the reality was that the violence was the product of a divided corporation, of new political structures and of widening political participation. Andrew Darcy, the brother of Patrick Darcy, testified that in the spring of 1642, the mayor, aldermen and freemen had met at the tholsel (town hall) at the instigation of Richard oge Martin and John Blake fitz Robert, both members of the town's council. ${ }^{96}$ There, they had appointed a Council of Eight. It was this body, meeting at the mayor's house, which had directed some of the townsmen to bargain for a ship with ordnance to strengthen the town and, when they had failed to agree a price with Clarke, had given the order to surprise the ship. ${ }^{97}$ At the same time there was an extension of political participation. Thus, the taking of the ship and the killing of the sailors, some claimed made 'a Towne act' even before they had come ashore, was afterwards declared by 'Publike and Generall vote' of the council and inhabitants at the Townsal 'the acte of the towne'. 98

Shared grievances, not least over the implications of Wentworth's plantation scheme for Connacht, and links between the O'Flaherty chiefs and members of the town's elite, ${ }^{99}$ had made it possible for a town that had until then resisted calls from within Connacht to join the rising to invite in the O'Flahertys to assist in the siege of the fort. But if relations between the Old English and Gaelic Irish had long moved from the hostility reflected in Galway's earlier by-laws excluding 'mere Irish' from the town, tensions remained. The invitation to the O'Flahertys to enter the town may, therefore, also have come from some of the more radical elements among the corporation and people. According to a deposition by a later mayor, Martin Lynch, the decision to invite them had been taken by some of the Council of Eight 'and with the permittance of the Inhabitants ... or the Major Vote'. ${ }^{100}$

Clanricarde's voluminous correspondence, while doubtless reflecting the familiar irritation of a landed aristocrat for a town which he found 'not wanting a large proportion of pride', offers valuable pointers to the divisions within Galway that explain the abandonment of negotiation and the resort to violence. According to Clanricarde, 'the better part of that town were overswayed by the greater'. ${ }^{101}$ Writing within the conventions of the contemporary language of sorts, Clanricarde was careful to draw a distinction between the better sort and those he called 'the multitude'. The 'disobedient and

${ }^{96}$ Examination of Andrew Darcy, 12 Nov. 1652, T.C.D., MS 830, f. 162r. Darcy was the brother of Patrick Darcy.

${ }^{97}$ Examination of Stephen Lynch, 19 Jan. 1652/3, T.C.D., MS 830, f. 201r. As Lynch deposed, he would not have gone to guard the ship after it was taken if the Council of Eight had not ordered it.

98 Examination of Andrew Darcy, 12 Nov. 1652, T.C.D., MS 830, ff 162r-162v; Examination of Steven Lynch fitz Andrew, 17 Jan. 1652/3, T.C.D., MS 830, f. 210r. See also the examinations of the Galway notary, Christopher French and Lt John Goll: T.C.D., MS 830, ff 163r, 243r-243v.

99 Duignan, 'Implications'; Jean M. Graham, 'Rural society in east Connacht 1600-1640' in Nicholas Stephens and R. E. Glasscock (eds), Irish geographical studies in honour of E. Estyn Evans (Belfast, 1970), pp 192-206. I am grateful to Paul Walsh and Clodagh Tait for drawing my attention to possible links between the O'Flahertys and Galway's ruling families, for which see M. J. Blake, Blake family records 1600 to 1700 (London, 1905), pp 404-05; idem, 'An account of the castle and manor of Bunowen in the barony of Ballinahinch and its successive proprietors from the fifteenth century to the present time' in Galway. Arch. Soc. Jn., ii (1902), pp 39-47.

${ }^{100}$ Examination of Martin Lynch, 24 Jan. 1653/4, T.C.D., MS 830, f. 262 r (my emphasis).

101 [Burke], Memoirs, pp 65, 134. 
unnatural act' of seizing the ship he attributed to 'the multitude' and in particular to 'some young men'. The town's endorsement of the act, he reported, was the work of 'a faction raised in the town ... [who had] compelled the mayor and graver sort to take it upon them'. Clanricarde identified what he variously called the 'active', 'illaffected' or 'malignant party'. This included members of the ruling elite, notably Sir Valentine, John and Francis Blake, the last 'stiled their general', and a number of clerics - Walter Lynch, Valentine Brown and Thomas Fleming - as well as the 'strong party of the young men'. ${ }^{102}$ The significant role played by the clergy, secular and regular, was reflected in their opposition to the subsequent restoration of order in May 1642, publicly continuing to advance against it the politics of conscience and threat of excommunication. ${ }^{103}$

In an attempt to subvert the rules on electing only Protestant mayors, the town had earlier introduced a popular franchise for the election of the mayor. After the seizure of the ship, this seems to have been extended in disregard of an earlier narrowing of the right of freeman to attend the town's meetings by the corporation. Now, with 'the young men and the malignant party ... resolved to govern', decisions were to be made by the 'votes of the multitude'. The mayor complained to Clanricarde of the overthrow of what he referred to as the 'ancient forms of government', with 'new erected captains, and private councils', frequent assemblies 'composed of a mixt multitude', where critical decisions were to be 'carried by voices'. When the town's rulers appeared not to adhere to this, there had been 'tumult and uproar' in the town with the young men claiming that they should have been called to court by the sounding of a drum and demanding 'they should have had their voices' too. ${ }^{104}$

While the town might subsequently (and perhaps speciously) claim a right by its charter to detain the ship, ${ }^{105}$ the violent capture of the Elizabeth and Francis demonstrated how the state's unpopular policies could forge an alliance, based on shared grievances between some members of the ruling circle and townsmen, which extended political participation and licensed violence by a group defined by their youth and lack of office. The holding of a special meeting at the tholsel which saw the freemen as well as mayor and aldermen appoint the Council of Eight; ${ }^{106}$ the private meetings in Walter Oge Martin's house and in Sir Valentine Blake's of a group including those not members of the corporation to debate whether to take the ship by force; and the enforced endorsement of the seizure as an act of the town at a meeting at the tholsel, to which many people flocked, all point to an extension of political participation.

But these changes were to be only temporary. In the short term, the violence was to lead to a restoration of the traditional structures of rule. In May, the corporation, renewing declarations of allegiance to the English nation and crown,

102 Ibid., pp 147, 139. Blake, a leading merchant and longest-serving member of the corporation, had lost the mayoralty on his refusal to take the oath of supremacy, but became mayor in the year 1643/4: McGrath, 'Managing the Windsor of Ireland', pp 67, 71; H.M.C., Manuscripts of ... the corporations of Waterford, Galway, etc., p. 492.

${ }_{103}$ Edward MacLysaght and H. F. Berry, 'Report on documents relating to the wardenship of Galway' in Anal. Hib., xiv (1944), pp 33-4.

${ }^{104}$ H.M.C., Manuscripts of ... the corporations of Waterford, Galway, etc., pp 94-5, 460; [Burke], Memoirs, pp 157, 124, 134, 141, 153.

${ }_{105}$ [Burke], Memoirs, p. 121. Since the cargo on Clarke's outward journey from Galway included illegally exported wool, the town claimed a right to confiscate the ship.

${ }^{106}$ Examination of Andrew Darcy, 12 Nov. 1652, T.C.D., MS 830, f. 162r; Examination of Stephen Lynch, 19 Jan. 1652/3, T.C.D., MS 830, f. 209r; Examination of Mary Bowler, 7 Mar. 1653/4, T.C.D., MS 830, f. 245r. 
submitted. ${ }^{107}$ In letters to the lords justices, Clanricarde had reported that most of 'the better sort' of the town were averse to the violent proceedings, but had been forced to join 'the mad resolution of the multitude'. ${ }^{108}$ Key members of the ruling group had opposed the violence as it happened and had been driven out of the town by popular hostility for protecting the English. ${ }^{109}$ When Sir Richard Blake later sought government support, he was able to present a certificate recording that he had been 'very serviceable to the English' in $1641 .{ }^{110}$ Patrick Darcy, when examined, said he had 'bemoaned' the seizing of the ship to the earl of Clanricarde, and he claimed to have been active with the town's recorder in subsequently expelling the O'Flahertys from the town. ${ }^{111}$ The later punishment by Galway's rulers of those involved in the murders suggests that while some may have been willing to tolerate robbing and killing, others (like their landed contemporaries) worried about the consequences of lower-class violence. Richard Kinowan, the bloodied rebel chased by Sir Thomas Blake, may have been the drunken man imprisoned with Lt Scott, but then released. But in 1643, by order of the new mayor, Richard Blake, and in a direct imitation of the punishment inflicted by the state on sixteenth-century English rebels, he was hanged on a gibbet at John Fox's door. ${ }^{112}$ The centrality of allegiance to the crown in the town's political culture may have facilitated the restoration of order, with Clanricarde's promise to take the town under the crown's protection until Charles came to Ireland and wider political participation being folded into corporate oath-taking. Taken individually and on the gospel, for 'the mutual protection of all catholicks, united for the service of God, king, and country, ${ }^{113}$ this required takers to swear to defend inter alia the monarchy and Catholic religion, 'to uphold and defend the rights, liberties, privileges, immunities and possessions of the corporation of Galway, and to carefully observe their lawful commands and defend all and every member thereof'. ${ }^{114}$ The restoration of order suggests that many, including most perhaps of the corporation, had been driven from above by the state's policies and from below by popular anti-Englishness and political agitation, to accept, if not welcome, the violence. But as elsewhere in Ireland fear of the crowd had come to outweigh fear of the crown.

Despite the archetypal evidence of Irish savagery provided by the brutal nature of John Fox's death, with its entanglement 'in the complex Irish heritage of symbolic

${ }^{107}$ History of the Irish Confederation and their war in Ireland, 1641-1643, containing a narrative of affairs of Ireland, by Richard Bellings, ed. J. T. Gilbert (2 vols, Dublin, 1882), ii, $33-4$.

108 [Burke], Memoirs, pp 15, 103, 109, 113, 131, 133, 139, 147.

109 Ibid., p. 140.

110 N.L.I., MS 11961, pp 171 [misno. as 172] -72. I am grateful to Prof. Harumi Goto for her help in obtaining a copy of this document.

${ }^{111}$ Examination of Patrick Darcy, 20 Dec. 1653, T.C.D., MS 830, f. 263v.

112 Three of the attackers were said to have been hanged by Captain Willoughby; Stephen Lynch fitz Andrew, one of the leaders of the attack on the ship, was later hanged at Galway in 1653: Examination of Margaret Roche, 9 Mar. 1653/4 2, T.C.D., MS 830, ff 238v-239r; Examination of Andrew Darcy, 12 Nov. 1652, T.C.D., MS 830, ff 162r-162v; Examination of Patrick Darcy, 20 Dec. 1653, T.C.D., MS 830, f. 263v.

113 [Burke], Memoirs, p. 125; H.M.C., Cal. of the manuscripts of the marquess of Ormonde, K. P., preserved at Kilkenny Castle, n.s., ii, 148-150.

114 [Burke], Memoirs, p. 101. 
mutilation' and the gendered transgression of the lusty, masculinised Irish woman, ${ }^{115}$ events at Galway did not provide copy for newsbooks or contemporary 'histories' of the 1641 Rising. Indeed, some well-informed contemporary histories of the violence at Galway omitted Fox's story. ${ }^{116}$ Ironically, while the five named as killers of the ship's crew were excepted from the 1652 treaty of surrender, a further clause reserving for punishment anyone else for murders committed before 19 March effectively wrote out of memory the deaths of Fox and others in the April episode. ${ }^{117}$ Nor, local studies apart, have the deaths at Galway in 1642 commanded much attention in later histories. ${ }^{118}$ In part, this probably reflects the welter of competing examples of even more gruesome violent episodes, real and imagined, on which later polemicists could draw.

Reading the depositions is overwhelmingly to listen to witnesses and victims who were, via the 1650s examinations, participants in victors' justice. As elsewhere in Ireland, the commonalty at Galway, Clanricarde's 'worst sort of people', ${ }^{119}$ were left mute, their beliefs and motivations ventriloquised by their victims, or recoverable only in the performative nature of their violence. ${ }^{120}$ Nonetheless, contextualising the violence at Galway challenges any simple reading of the killings as spontaneous acts of Irish savagery. It suggests that understanding the episodes there in their own right can make a more general contribution to understanding popular violence in the 1641 Rising and the role of crowds in early modern Ireland.

Despite the claims and fears of the English deponents, there were only a small number of deaths at Galway (though as we have noted not all those mentioned in the depositions merited investigation). Many of the English were able to escape to the fort and all finally on its surrender to leave Galway. A partial explanation for the discrepancy in the level of violence is, of course, to be found in the English deponents' exaggerated fears of such violence. The significant recalibration downwards of levels of violence that has resulted from ongoing work on the 1641 depositions has rightly challenged previous, polemically-driven and partisan estimates of the number of deaths and murders. Nevertheless, recent recognition of the potential offered for a reading of the depositions informed by trauma studies and by a history of the emotions suggests the possibilities of a more nuanced reading of

115 Marie-Louise Coolhan, Women, writing, and language in early modern Ireland (Oxford, 2010), pp 153-4; Patricia Palmer, "“An headless ladie" and "a horses loade of heades": writing the beheading' in Renaissance Quarterly, 1x, no. 1 (2007), pp 25-57; eadem, "“A horses loade of heades": conquest and atrocity in early modern Ireland' in Palmer, The severed head and the grafted tongue: literacy, translation and violence in early modern Ireland (Cambridge, 2014), pp 12-35; David Edwards, "Some days two heads and some days four"' in History Ireland, xvii, no. 1 (2009), pp 18-21; Dianne Hall, 'Fear, gender and violence in early modern Ireland' in Michael Champion and Andrew Lynch (eds), Understanding emotions in early modern Europe (Turnhout, Belgium), p. 229; William Palmer, 'Gender, violence and rebellion in Tudor and Stuart England' in Sixteenth Century Journal, xxiii, no. 4 (1972), pp 699-712.

${ }_{116}$ History of the Irish Confederation, ed. Gilbert, pp 50-109.

${ }_{117}$ Dunlop, Ireland, i, 164, n. 4(4).

118 Hardiman, History, pp 111-15; O’Sullivan, Old Galway, pp 238-40; Seán Spellissy, The history of Galway: city and county (Limerick, 1999), pp 57-63.

119 [Burke], Memoirs, p. 110.

120 John Walter, 'Performative violence and the politics of violence in the 1641 depositions' in Ó Siochrú \& Ohlmeyer (eds), Ireland, 1641, pp 134-52. 
how we might assess the experience of violence. ${ }^{121}$ The Galway survivors' later recollection of events there, even in the constrained space permitted them by the process of deposing to order, underline the importance of not simply measuring the impact of violence in 1641 by numbers alone. The English forced to remain in Galway were not cut off from the reports and rumours of violence elsewhere, not least the massacre at nearby Shrule bridge. ${ }^{122}$ The trauma of witnessing violent death and of having to live cheek by jowl with its perpetrators in what was a closely-packed town is captured in their memories of the gibbet 'whereon to hang the English', erected on their arrival at the cross in the centre of the city and only taken down at their departure. ${ }^{123}$

Given the evident hostility reported in the depositions, what perhaps needs more explanation is why there was not more anti-English violence. As we have seen, in a divided city not all approved of the violence, even those like Sir Thomas Blake who were otherwise very active in the conflict against the English. Others, besides Sir Richard Blake, were later able to seek government support on the basis of help they had given to the English. The ship's surgeon had been saved by an anonymous, musket-carrying native speaker, and Lt Scott reported that it was the intervention of another townsman that had saved him from violence at the hands of his attackers. ${ }^{124}$ Catholic clergy at Galway too had sought to stop the killings, employing Catholic rites, as in other continental risings, to do so. ${ }^{125}$ The deaths on the ship were in part a consequence of its ultimately violent seizure. There is evidence to suggest that behind the O'Flahertys' violence was a familiar pattern of tit-for-tat killing. ${ }^{126}$ The minister William Hamond testified that on the same day as the killing of Fox and the others, the soldiers of the fort had killed kill two or three of the rebels in a skirmish, and those he termed 'the rogues', 'in Coole bloud (to ag[g]ravate their malice)', afterwards killed three (in reality, more) of the English, one of whom was Mrs Collins. ${ }^{127}$ But even the relative wealth of documentation at Galway does not allow us to recover the personal backstories that might explain the selection of the April victims, of whom otherwise little is known. John Fox was a ship's chandler and had given shelter to the carpenter wounded in the attack on the ship; Mrs Collins, a 'worthy \& religious woman', was a kinswoman of Doctor Boyle, archbishop of Tuam. ${ }^{128}$ The nature of the

121 See the essays in Fionnuala Dillane, Naomi McAreavey and Emilie Pine (eds), The body in pain in Irish literature and culture (Cham, Switzerland, 2016), and Clodagh Tait, "Whereat his wife took great grief and died": dying of sorrow and killing in anger in seventeenth-century Ireland' in M. J. Braddick and Phil Withington (eds), Popular culture and political agency in early modern England and Ireland (Woodbridge, 2017), pp 267-84.

${ }^{122}$ Inga Jones, "Holy war"? Religion, ethnicity and massacre during the Irish rebellion 1641-2' in Darcy, Margey \& Murphy (eds), The 1641 depositions, pp 138-40.

123 Deposition of John Sheeley, Magdelin Smith, Margaret Rollright, 25 Mar. 1644, T.C.D., MS 830, f. 169r; Prunty \& Walsh, Gaillimh/Galway, p. 3; Walsh, Renaissance Galway, pp 44-5, pl. 12.

124 Hardiman, History, p. 115; Examination of Robert Rawlins, 5 Feb. 1653/4, T.C.D., MS

830, f. 197r; Examination of Hiber Scott, 23 Dec. 1653, T.C.D., MS 830, f. 226v.

125 See, for example, Peter Burke, 'The Virgin of Carmine and the revolt of Masaniello' in Past \& Present, xcix (1983), pp 11-12, 20.

126 On which, see Robert Armstrong, Protestant war: the 'British' of Ireland and the Wars of the Three Kingdoms (Manchester, 2005), pp 32-4.

127 Deposition of William Hamond, 14 Aug. 1643, T.C.D., MS 830, ff 134r-134v.

128 Examination of Andrew Darcy, 12 Nov. 1652, T.C.D., MS 830, f. 162v; Examination of Martha Lone, 23 Feb. 1653/4, T.C.D., MS 830, f. 242v. 
evidence perfectly illustrates the problems when using the depositions of seeing beyond the stereotypical characterisations of an Irish atrocity.

If it is not possible to recover individual life stories, contextualising the violence does allow us to see the politics behind its occurrence. The policy of anglicisation had challenged Galway's Old English rulers' self-identity, slighted their faith, and threatened a collective loss of power. It had endangered Galway's conception of itself as an independent, but loyal city-state, and had called into question the allegiance to the crown that had been the bedrock of the town's political identity. It provoked anti-English hostility, of which the killings were one expression. It created division among Galway's rulers and increased popular political participation in the radical, if ultimately temporary, changes to the town's ruling structures that had parallels in the experience of other Irish cities in the 1640 s. $^{129}$ It had finally promoted a confessional union of Catholics between the Old English and Gaelic Irish in action against the English in the fort and in the town.

Contextualising the episodes of violence reveals that the 'unofficial' attack on the ship was driven by fears of further persecution of Catholics. It paralleled the plans originally envisaged and encouraged by the corporation. Nor were the killings in April merely acts of spontaneous violence, whatever the possible and problematic relationship between retaliation, drink and violence. Permitted but not commanded, ${ }^{130}$ they drew on shared grievances. They too had their origins in the political and religious changes pursued by the state. Under the pressure of state interference, confessional unity had come to replace ethnic division. As Aidan Clarke wryly observed, 'the union of Catholics in Ireland was, from first to last, a Protestant achievement, not a Catholic one'. ${ }^{131}$

\section{VIII}

In a thoughtful recent essay Brendan Kane has offered his reflections on whether evidence exists for what he calls 'operative non-elite politics', 'a tradition of en masse political agitation' in early modern Ireland. ${ }^{132}$ His answer to his own question, though nuanced, would seem to be in the negative. But Kane makes an exception for 1641 , though he does not regard events therein 'as an expression of an ingrained and developed sense of plebeian political 'right' or expectation'. Some may find that his distinction between popular agency that seeks 'to shape the character of the state and governance' and popular agency that seeks 'simply to rebuff certain of its local manifestations' both raises the bar too high and is a distinction in practice difficult to maintain. As Tim Harris has observed, 'People were politicized in the first place as a result of being subject to government'. ${ }^{133}$

${ }^{129}$ See Micheál Ó Siochrú, 'Civil autonomy and military power in early modern Ireland' in Journal of Early Modern History, xv, no. 1 (2011), pp 31-57.

${ }^{130}$ I owe this perceptive phrase to Paul Walsh.

131 Clarke, Old English, pp 10-11.

132 Brendan Kane, 'Popular politics and the legitimacy of power in early modern Ireland' in Campbell, Fitzpatrick \& Horning (eds), Becoming \& belonging, pp 328-43.

133 Tim Harris, 'Publics and participation in the three kingdoms: was there such a thing as "British public opinion" in the seventeenth century?' in Journal of British Studies, lvi (2017), p. 736. 
Other work on violence and crowd actions before $1641,{ }^{134}$ on the public role of the Catholic clergy, ${ }^{135}$ on the experience of governance and the orality of the communicative practices of authority in early modern Ireland has begun to lay the groundwork for understanding how a popular politics could emerge in early modern Ireland. ${ }^{136}$ Exploring the relationship between these pre-existing patterns of protest and popular politics in the rising and the potential for further politicisation this represented, will help to evaluate to what extent it drew on an earlier tradition of crowd actions and to what extent it created a new space for popular politics (though, as ever, the social dimension of the popular in crowds before and during the rising remains relatively unexplored and problematic). Clearly, the experience of 1641 promoted new forms of political engagement, not least in mass oath-taking, an enlarged public role for the Catholic clergy and the new structures of confederate government, about which the 1641 depositions also provide valuable evidence. ${ }^{137}$ That this did not lead to the levels of politicisation and radicalisation evident in the contemporaneous English Revolution raises important questions of comparative history. ${ }^{138}$ The increased popular political participation that accompanied the violence in Galway doubtless reflected its developed structures of urban government and the advanced political culture of what the town itself chose to call a commonwealth. But Galway was unusual, not unique, in early modern Ireland. All crowd actions can be seen as political to the extent that they represent a claim to negotiate, interrogate and exercise power. Seen in context, the violence in 1642 was political; it was both a consequence of and contributor to political change at Galway. ${ }^{139}$

${ }^{134}$ See the works listed in footnote 3 above.

135 David Finnegan, 'The influence of the Irish Catholic clergy in shaping the religious and political allegiances of Irish Catholics, 1603-1641' in Armstrong \& Ó hAnnrachain (eds), Insular Christianity, pp 107-28; Tadhg Ó hAnnrachain, 'Rebels and confederates: the stance of the Irish clergy in the 1640s' in J. R. Young (ed.), Celtic dimensions of the British civil wars (Edinburgh, 1997), pp 96-115.

${ }^{136}$ Eamon Darcy, 'Political participation in early Stuart Ireland' in Journal of British Studies, lvi (2017), pp 773-96; idem, 'The Confederate Catholics of Ireland and popular politics' in Patrick Little (ed.), Ireland in crisis, (Manchester, 2019), pp 172-92; Raymond Gillespie, 'Negotiating order in early seventeenth-century Ireland' in M. J. Braddick and John Walter (eds), Negotiating power in early modern society: order, hierarchy and subordination in Britain and Ireland (Cambridge, 2001), pp 188-205; 'Political ideas and their social contexts in seventeenth-century Ireland' in Jane Ohlmeyer (ed.), Political thought in seventeenth-century Ireland: kingdom or colony (Cambridge, 2000), pp 107-27.

137 John Morrill, 'An Irish protestation? Oaths and the Confederation of Kilkenny' in Braddick \& Withington (eds), Popular culture \& political agency, pp 243-65. For a revealing study of the intersection between mass oath-taking and new structures of local government revealed in the 1641 depositions, see T.C.D., MS 818 and McHugh, 'Catholic insurrection in Wexford, 1641-2', pp 214-40.

${ }^{138}$ For the radical potential of mass oath-taking, see John Walter, Covenanting citizens: the Protestation Oath and popular political culture in the English Revolution (Oxford, 2017).

${ }^{139}$ Research for this paper was undertaken while holding a visiting fellowship at the Long Room Hub Arts and Humanities Research Institute, Trinity College, Dublin. I am indebted to the director, Professor Jane Ohlmeyer and to fellow members for their warm hospitality and stimulating discussions, and to the audience for questions when an earlier version of the paper was given as a public lecture there. John Morrill, Jane Ohlmeyer, Micheál Ó Siochrú, Clodagh Tait, and Patrick Walsh kindly read an earlier draft and, together with Robert Armstrong, Eamon Darcy, Bríd McGrath, Raymond Gillespie and the two anonymous readers for I.H.S., were generous with advice and suggestions. 